ANDRÉ LUÍS FERREIRA GRANDIS

\title{
A INFLUÊNCIA DA PRESENÇA MILITAR DOS ESTADOS UNIDOS NA AMÉRICA DO SUL NA PERSPECTIVA DA \\ SOBERANIA NACIONAL BRASILEIRA
}

Brasília

2010 
ANDRÉ LUÍS FERREIRA GRANDIS

\section{A INFLUÊNCIA DA PRESENÇA MILITAR DOS ESTADOS UNIDOS NA AMÉRICA DO SUL NA PERSPECTIVA DA SOBERANIA NACIONAL BRASILEIRA}

Trabalho de Conclusão de Curso de Especialização em Relações Internacionais para a Universidade de Brasília, apresentado como requisito parcial à obtenção do título de Especialista em Relações Internacionais

Orientador: Professor Alcides C. Vaz

Brasília

2010 


\section{FICHA CATALOGRÁFICA}

Grandis, André Luís Ferreira.

A influência da presença militar dos Estados Unidos na América do Sul na perspectiva da Soberania Nacional Brasileira/ André Luís Ferreira Grandis; Orientador:

Alcides C. Vaz - Brasília, 2009.

$50 \mathrm{p}$.

Trabalho de Conclusão de Curso. Instituto de Relações Internacionais / Universidade de Brasília.

Curso de Especialização em Relações Internacionais.

1. Presença Militar dos Estados Unidos. 2. Política Externa do Brasil. 3. Soberania Nacional. 
Aos meus pais pela vitória conquistada pela vida e incentivo de constante luta e perseverança. 


\section{AGRADECIMENTOS}

Ao amigo e orientador Prof. Dr. Alcides C. Vaz pelas diretrizes seguras e permanente incentivo.

À minha esposa, permanente atenta ao meu ganho de conhecimento e companheira de vida.

Às minhas filhas, elementos de amor e segurança. 
"Talvez nos recordemos deste momento histórico como aquele em que o Ocidente decidiu por ele mesmo no Século XXI, não em termos de Geografia, de Raça, de Religião, de Cultura ou de Língua, mas em termos de valores tais como Liberdade e Democracia”.

Paul Wolfowitz - Council of Foreign Relations, em 23/3/2003 (tradução livre do autor). 


\section{RESUMO}

O estudo analisa a influência externa da política do Governo dos Estados Unidos que, em linhas gerais, tem como objetivo a defesa dos interesses norte-americanos no exterior segundo a Doutrina de Segurança Nacional dos EUA. O trabalho mostra como é aplicada esta política em nível estratégico na América do Sul; apresenta os aspectos de maior relevância da Doutrina de Segurança Nacional daquele país; descreve as metas estratégicas estabelecidas pelo Departamento de Estado norte-americano para atender aos seus interesses na América do Sul; e destaca o papel do Comando Sul dos EUA como instrumento de aplicação dessa Política para a Região. Apoiando-se na conjuntura interna atualizada dos países sul-americanos, descreve como a superpotência mundial faz a expansão do seu Poder Nacional na América do Sul, particularmente o militar, e mostra os reflexos para o Brasil dessa expressiva presença no subcontinente, após uma abordagem crítica sobre as possibilidades brasileiras atuais de projeção de Poder, na Região. Enfatiza, por fim, a crescente ingerência dos EUA nos assuntos internos dos países sul-americanos, com risco de comprometimento, em alguns casos, de suas soberanias.

Palavras-chave: Presença Militar dos Estados Unidos, Política Externa do Brasil, Soberania Nacional. 


\section{LISTA DE FIGURAS}

Figura 1 - Mapa da América Central e da América do Sul sob a jurisdição do Comando Sul 24 dos Estados Unidos para Hemisfério Ocidental 


\section{LISTA DE SIGLAS}

COCOM - Comandos de Combate do Departamento de Defesa dos EUA

DEA - Drug Enforcement Administration

DIA - Defense Intelligence Agency

ELN - Exército de Libertação Nacional

EUA - Estados Unidos da América do Norte

FAE - Força Aérea Equatoriana

FAN - Força Armada Nacional

FARC - Forças Armadas Revolucionárias da Colômbia

FE - Forças Especiais

FELCN - Força Especial de Luta contra o Narcotráfico

FOL - Forward Operating Locations

FTCS - Força Tarefa Conjunta do Sul

GOPE - Grupo de Operações Especiais

IAAFA - Inter-American Air Force Academy

IMET - Programa Internacional de Treinamento e Educação Militar

INSS - Institute for National Strategic Studies

JIATF-East -Joint Interagency Task Force-East

JSSROC - Centro de Operações Conjuntas de Reconhecimento e Vigilância

JTF- Bravo - Joint Task Force-Bravo

MRC - Movimento Revolucionário Carapaica

NATO - Organização do Tratado do Atlântico Norte

NAVSCIATTS-Naval Small Craft Training

NDU - National Defense University

$N D U$ - Universidade de Defesa Nacional (National Defense University)

NMD - National Missile Defense

NSA - National Security Agency

ONU - Organização das Nações Unidas

OTAN - Tratado do Atlântico Norte

PIB - Produto Interno Bruto

PNP - Polícia Nacional do Peru

RPC - República Popular da China

SEALs - Sea Air Land Team

SENAD - Secretaria Nacional Antidrogas

SOUTHCOM - Comando do Sul dos Estados Unidos

UMOPAR - Unidade Móvel de Patrulhamento Rural

USAF - United States Air Force

USMC - United States Marines Corps

WHINSEC - Wester Hemisphere Institute for Security Cooperation 


\section{SUMÁRIO}

LISTA DE FIGURAS $\quad 8$

LISTA DE SIGLAS 9

INTRODUÇÃO

CAPÍTULO 1 - POLÍTICA DE SEgURANÇA DOS EUA PARA A AMÉRICA DO 16 SUL

1.1 Política de Segurança dos EUA após 11 de setembro de 2001

1.2 Ações Preventivas dos EUA para a América do Sul 18

1.3 Metas do Plano Estratégico do Departamento de Estado dos EUA 19

1.4 Desafios de Segurança para os EUA na América do Sul 19

CAPÍTULO 2 - O COMANDO SUL DOS EUA 23

2.1 Estruturas do Comando Sul 24

2.2 Estratégias do Comando Sul 25

2.3 Principais atividades do Comando Sul 28

CAPÍTULO 3 - CENÁRIO DE SEGURANÇA DA AMÉRICA DO SUL 29

3.1 Narcotráfico - uma questão de segurança nacional 30

3.2. As dinâmicas regionais e a questão da Colômbia e Venezuela 31

CAPÍTULO 4 - BRASIL: REFLEXOS DA PRESENÇA MILITAR DOS EUA NA 33 AMÉRICA DO SUL

4.1 Segurança e Defesa Nacional 34

4.2 O Papel do Brasil em relação à segurança na América do Sul 35

4.3 Brasil - incertezas e instabilidade 37

CAPÍTULO 5 - CONCLUSÕES 41

$\begin{array}{ll}\text { REFERENCIAS } & 49\end{array}$ 


\section{INTRODUÇÃO}

Este estudo apresenta uma análise da Política de Segurança Nacional dos EUA para a América do Sul, após a Guerra Fria até os dias atuais, e sua influência na questão da soberania das nações desta Região, principalmente para o Brasil, tendo como foco a presença militar dos EUA na América do Sul.

Esta política foi definitivamente alterada no contexto internacional após o dia 11 de setembro de 2001, quando os Estados Unidos da América sofreram um atentado terrorista, e colocaram em sua política externas novas variáveis, objetivos, novas perguntas e novas respostas.

Para muitos estudiosos do tema, os Estados Unidos da América saíram da Guerra Fria como superpotência única no sistema internacional. O colapso da URSS e do bloco do Leste deixou um caminho livre para a configuração de um novo sistema internacional marcado pela unipolaridade. Verificou-se o início de um novo sistema internacional, com diversas alterações na política externa norte-americana - país que continua sendo o mais forte militarmente, com novas armas, novos objetivos e com uma posição de defesa reforçada.

Atualmente, os alvos de longo prazo da nova estratégia de segurança e de política energética dos Estados Unidos estão muito além dos inimigos públicos apresentados ao mundo no dia 11 de setembro de 2001. Para os EUA, um dos principais objetivos é bloquear a emergência de concorrentes geoestratégicos e permitir o "século americano".

A América do Sul, com características comuns de instabilidade econômica, forte dependência da ajuda financeira externa, baixos índices sociais e, com exceção de poucos países, fragilidade democrática agravada por crises de governabilidade, assiste ao crescimento da influência e da presença norte-americana na Região.

O Departamento de Estado dos EUA classifica diversos fatores existentes na América do Sul como ameaças a seus interesses nacionais, o que para ele justifica a aplicação de uma política externa pragmática e ambiciosa para esta Região.

Alguns aspectos relevantes são privilegiados pelo Governo dos EUA, quando este aponta como estratégia para a Região a necessidade de obter e manter uma base militar bem 
estruturada, que sirva de apoio a operações militares, bem como o reforço às ações de combate ao narcotráfico, e o estabelecimento de uma rede de instalações militares de comando e controle, se possível em todos os países.

Antes de avaliar a atual Política de Segurança Nacional dos EUA para a América do Sul, faz-se necessário e essencial apresentar um breve comentário do foco da política de Segurança Nacional dos EUA, adotada pelos últimos presidentes dos Estados Unidos com relação à América do Sul.

Segundo Pereira (2009, p. 2-7), o tráfico de drogas já tinha ganho contorno de ameaça transnacional desde o governo Nixon na década de 1970, e levou à criação da DEA - Drug Enforcement Administration, no governo Reagan na década de 1980. O governo George H. Bush tornou concreta a DEA nas reuniões de Cúpula anti-drogas de Cartagena em 1990, na Colômbia e na Cúpula de San Antonio, realizada em 1992 no Texas. No governo Clinton a preocupação com o tráfico de drogas tornou-se uma das prioridades da segurança nacional. As ações no continente sul-americano durante a década de 1990 não se limitaram ao combate do crime. Clinton enfatizou a cooperação e os investimentos, com a promoção de reformas comerciais para a liberalização dos mercados e o combate à produção e o tráfico de drogas.

Com a chegada ao poder de um executivo republicano, liderado por George W. Bush, a postura internacional norte-americana foi sendo modificada a partir das naturais linhas que herdou dos anos da Administração Democrata do Presidente Bill Clinton. O então novo governo imprimiu o seu cunho republicano, que se fazia sentir na forma como encarava as obrigações multilaterais do seu país. Stephen M. Walt, no seu artigo Beyond Bin Laden, escreveu ${ }^{1}$ :

Diferente de um explícito desdém de acordos multilaterais e colocação de mísseis de defesa, a prioridade da política exterior de George W. Buch e sua administração não são radicalmente diferentes de seus antecessores (Reshaping US Foreign Policy vol. 26, № 3 Inverno de 2001/02, p. 5678).

\footnotetext{
1،....apart from an explicit disdain for certain multilateral agreements and a fixation on missile defense, the foreign policy priorities of George W. Bush and his administration were not radically different from those of their predecessors" (Reshaping US Foreign Policy, vol. 26, $\mathrm{N}^{\circ}$ 3, Inverno de 2001/02, p. 56-78).
} 
$\mathrm{Na}$ prática, o que se assistiu foi a um natural desencontro entre a posição norteamericana e a dos seus parceiros ocidentais em matéria de tratados internacionais, como se pode verificar em alguns exemplos: em relação ao Tribunal Penal Internacional, a administração norte-americana entendia que não deveria assinar qualquer acordo que pudesse vir a ser lesivo aos interesses e soberania norte-americanos; os países da UE assinaram em bloco; quanto ao Protocolo de Quioto, a administração norte-americana insistiu nas afirmações de que se assinassem o protocolo estariam comprometendo a sua indústria nacional e, conseqüentemente, os seus interesses nacionais, embora este protocolo tenha sido assinado pela quase totalidade dos países ocidentais; em relação ao Tratado de Proibição Total de Testes Nucleares (Compreensive Test Ban Treaty), os EUA recusaramse a assinar, e saíram unilateralmente do Tratado Antimíssil Balísticos; os EUA são contra o Tratado da Biodiversidade, pois, para eles, o Tratado traduz um impedimento a futuros avanços na Biotecnologia. As assimetrias não são apenas essas. Os desafios de política externa colocados nos dias atuais para o Presidente Barack Obama são complexos. O foco desta análise é a política externa para a América do Sul, com ênfase na questão da Segurança Nacional e seus reflexos para a soberania das nações da Região e a brasileira.

\section{Problema de Pesquisa}

O problema a ser analisado no presente estudo são os aspectos da política de Segurança Nacional dos EUA que amparam as suas ações militares na América do Sul e suas principais influências na soberania dos países da América do Sul e a soberania do Brasil.

O objetivo geral do estudo é apresentar os reflexos, especialmente para o Brasil (único país da América do Sul que não recebe assistência militar dos EUA desde 1977), das atividades militares norte-americanas nos países da América do Sul. Para tanto, foi exposta as principais características do Comando Sul dos EUA, o Grande Comando Combinado, que operacionaliza as decisões político-estratégicas para a América do Sul, e verificado como tem sido para a soberania dos países vizinhos do Brasil a presença militar dos EUA.

A metodologia escolhida para este estudo é a análise documental. Para Richardson (1999), o método qualitativo, usado neste estudo, "difere, em princípio, do quantitativo à 
medida que não emprega um instrumental estatístico como base do processo de análise de um problema" (1999 p. 79), e justifica-se por ser uma forma adequada para entender a natureza de um fenômeno político, ou situações em que observações qualitativas são usadas como indicadores do funcionamento de estruturas políticas e sociais. A escolha dependeu da natureza do fenômeno analisado e do material que o método permitiu coletar. Na coleta de dados, os documentos foram selecionados e analisados para, então, realizar uma reflexão aprofundada do fenômeno em questão.

Para a realização deste estudo utilizou-se, como fontes de pesquisa, além da bibliografia sobre o tema, documentos de fontes primárias e secundárias. Foram pesquisados os documentos da Estratégia Nacional de Defesa (1996 e 2005); uma ampla coleta de dados foi realizada junto aos Órgãos de Inteligência do Ministério da Defesa, Comando da Aeronáutica, Comando da Marinha e do Exército Brasileiro, para consolidar as informações provenientes das Adidâncias Militares e de Defesa dos países sulamericanos, que mantêm um banco de dados atualizado sobre o tema. Além disso, foi realizada uma análise dos discursos e declarações políticas referentes às questões de segurança e defesa; bem como as convenções e tratados hemisféricos e sub-regionais, documentos emitidos pelo Conselho Permanente, pela Comissão de Segurança, princípios e procedimentos das questões de segurança e defesa dos países da América do Sul. Além das consultas a sítios de internet de reconhecidos institutos e instituições como fontes de pesquisa, bem como textos de análise de conjuntura.

Antes de dar início a análise propriamente dita, faz-se necessário esclarecer os conceitos de Defesa, Segurança e Soberania nacional. Vergonttini (1986), no verbete Defesa, do Dicionário de Política, de N. Bobbio, N. Mattteucci e G. Pasquino (1986, p.312-318), faz um distinção clara entre Defesa e Segurança e Soberania.

A situação de estabilidade do sistema institucional e de desenvolvimento ordenado da coletividade nacional no quadro dos princípios constitucionais, originariamente englobados num ordenamento, indentifica-se como a sua segurança. Esta enquanto síntese de conservação e desenvolvimento, conforme os princípios constitucionais, é o máximo valor jurídico tutelado. Em relação a ela, o conceito de Defesa assume um conceito estritamente instrumental, que compreende todas as modalidades organizativas e funcionais destinadas a garantir os valores essenciais sintetizados no conceito de Segurança...

$\mathrm{O}$ conjunto de aparelhos destinados em primeiro lugar e de maneira exclusiva à tutela da segurança, no âmbito das relações internacionais, qualifica-se como organização de Defesa. Neste caso a Defesa coincide 
prevalentemente com a organização das Forças Armadas do Estado. Sempre no sentido instrumental, fala-se, propriamente, de Defesa em relação à atividade desenvolvida para garantir a Segurança, ameaçada por fatores tanto de origem interna quanto externa (Vergonttini,1986, p. 512; Grifo nosso).

Sergio Bova, no verbete Serviços de Segurança, do Dicionário de Política, enfatiza que os Serviços de Segurança:

... compreendem os órgão de Estado encarregados de coletar informações políticas, militares e econômicas sobre os demais Estados, particularmente os Estados inimigos ou potencialmente, por meio da espionagem. Sua função é impedir a atividade de espionagem estrangeira em território nacional, e onde quer que seja possível (atividade de contra-espionagem), bem como a de coordenar todo um conjunto de ações que possam enfraquecer a força política, militar e econômica dos Estados Inimigos (BOVA, 1986, p. 1147).

A definição de Soberania apresentado por N. Mattteucci é:

"conceito político-jurídico de Soberania indica o poder de mando de última instância, numa sociedade política"... "Trata-se da racionalização jurídica do poder no sentido de transformação em poder legítimo, em poder de fato, em poder de direito".

O significado moderno de Soberania surge ao mesmo tempo em que o de Estado, no final do século XVI, indicando o poder estatal... Sujeito único e exclusivo da política “(N. Mattteucci, 1986, p. 1179).

Estes são conceito que balizam tanto o documento de estratégia de defesa do Brasil, como o dos Estados Unidos da América, além da formação do Ministério da Defesa e sua estrutura hierárquica e relação com os demais Ministérios que compõem a Política Estratégica de Defesa do Brasil, a qual será apresentada e discutida adiante.

A Monografia está organizada em cinco capítulos. O primeiro apresenta os aspectos da Política de Segurança Nacional norte-americana para a América do Sul. O segundo descreve a estrutura, estratégias e principais atividades do Comando Sul. No capítulo três é feita uma análise da presença militar dos EUA nos países da América do Sul, com exceção do Brasil, e apresenta algumas considerações sobre o cenário militar na América do Sul. No quarto capítulo há uma análise dos reflexos no Brasil da presença militar dos EUA na América do Sul, sob a perspectiva da soberania brasileira. No capítulo cinco estão as conclusões. 


\section{CAPÍTULO 1}

\section{POLÍTICA DE SEGURANÇA DOS EUA PARA A AMÉRICA DO SUL}

\subsection{Política de Segurança dos EUA após 11de setembro de 2001}

Fatores não tradicionais como fonte de ameaça à segurança dos Estados nas relações internacionais contemporâneas provocaram alteração quanto ao entendimento acerca da natureza e intensidade relativa das fontes de insegurança no pós-Guerra Fria. O novo cenário internacional assinala para a emergência de uma agenda de temas e conteúdos de importância distinta para os Estados Unidos e para a América do Sul. Os riscos comuns que poderiam afetar a segurança dos EUA e das nações da Região foram acrescidos por outros ou deixaram de existir.

Como conseqüência imediata dos acontecimentos de 11 de setembro, o governo Bush voltou a sua atenção para a guerra contra o terrorismo. Primeiramente, na frente doméstica, o governo tentou e recebeu resolução conjunta do Congresso para a autorização do uso do poderio militar no exercício da autodefesa legítima.

Segundo a resolução, o presidente pode utilizar toda a força necessária e apropriada contra as nações, organizações ou pessoas que determine como tendo planejado, autorizado, cometido ou auxiliado os ataques terroristas que ocorreram em 11 de Setembro de 2001, a fim de evitar qualquer ato futuro de terrorismo internacional contra os Estados Unidos. A resolução foi aprovada por 98x0 no Senado e 420x1 na Câmara dos Deputados.

Em seguida, os Estados Unidos tentaram e receberam o voto unânime do Conselho de Segurança das Nações Unidas em 28 de setembro do mesmo ano.

A Resolução $137^{2}$ exige que os Estados membros criminalizem as atividades financeiras da Al-Qaeda, compartilhem informações e tomem medidas para evitar a ação destes.

\footnotetext{
${ }^{2}$ Adotada com base no Capítulo VII da Constituição das Nações Unidas, que atribui ampla autoridade ao Conselho de Segurança para que execute sua decisão e faça com que a resolução comprometa todos os países membros das Nações Unidas.
} 
A opinião pública, que estava profundamente dividida desde a eleição presidencial de novembro de 2000, deu um amplo apoio, não apenas ao esforço de guerra, mas ao próprio presidente. Embora a resolução tenha efeito mais simbólico do que prático, ela dá legitimidade multilateral para a batalha liderada pelos norte-americanos contra o terrorismo. Os 19 membros da OTAN invocaram o Artigo $\mathrm{V}^{3}$ do Tratado do Atlântico Norte pela primeira vez na história da aliança. Essa vitória ocorreu muito mais rapidamente e com muito menos perdas que esperavam muitos observadores e foi comemorada pela população local, que se viu liberta do regime opressivo dos Talibãs.

Desde o princípio, entretanto, o presidente tinha sido explícito ao afirmar que a guerra contra o terrorismo não seria breve e, em janeiro de 2002, no discurso para uma sessão conjunta do Congresso, ele descreveu o que logo ficou conhecido como a "Doutrina Bush".

... (Nós) fecharemos acampamentos de terroristas, destruiremos planos terroristas e traremos os terroristas para a justiça. E... devemos evitar que os terroristas e regimes que querem armas químicas, biológicas ou nucleares ameacem os Estados Unidos e o mundo... Ainda assim, o tempo não está do nosso lado. Não aguardarei os eventos enquanto os perigos se acumulam. Não pararei enquanto os perigos chegam cada vez mais perto. Os Estados Unidos da América não permitirão que os regimes mais perigosos do mundo nos ameacem com as armas mais destrutivas do planeta (Foreign Affairs - Novembro/Dezembro, vol. 80, nº 6.).

O Governo norte-americano elaborou uma nova Doutrina de Segurança Nacional, que considerava o inimigo imediato e direto dos EUA todos os países que dessem proteção, ou seja, fossem tolerantes com as "redes terroristas", e aos países que pretendiam desenvolver e produzir armas de destruição em massa.

\footnotetext{
${ }^{3}$ As Partes concordam em que um ataque armado contra uma ou várias delas na Europa ou na América do Norte será considerado um ataque a todas, e, conseqüentemente, concordam em que, se um tal ataque armado se verificar, cada uma, no exercício do direito de legítima defesa, individual ou coletiva, reconhecido pelo artigo 51 da Carta das Nações Unidas, prestará assistência à Parte ou Partes assim atacadas, praticando sem demora, individualmente e de acordo com as restantes Partes, a ação que considerar necessária, inclusive o emprego da força armada, para restaurar e garantir a segurança na região do Atlântico Norte. Qualquer ataque armado desta natureza e todas as providências tomadas em consequiência desse ataque são imediatamente comunicados ao Conselho de Segurança. Essas providências terminarão logo que o Conselho de Segurança tiver tomado as medidas necessárias para restaurar e manter a paz e a segurança internacionais.
} 
Na nova doutrina da era Bush, o interesse prioritário para os EUA passou a ser o combate sem tréguas ao terrorismo internacional, embora também considerasse a relevância da implantação de um escudo antimíssil para o território norte-americano.

\subsection{Ações Preventivas dos EUA para a América do Sul}

Os Estados Unidos têm mantido a opção das ações preventivas para conter uma ameaça relevante para a segurança da América do Sul. Quanto maior a ameaça, maior é o risco da incapacidade de agir - e mais necessário será o caso de tomar medidas antecipatórias de defesa, mesmo com alguma incerteza de quando e onde será o ataque do inimigo. Para antecipar ou prevenir tais atos hostis por nossos adversários, os Estados Unidos irão, se necessário, agir preventivamente (The National Security Strategy of the United States of Americ).

A afirmativa acima transcrita corresponde a um trecho do documento apresentado pelo Governo estadunidense, em setembro de 2002, que expõe as diretrizes da política externa americana no âmbito da segurança nacional.

O pensamento americano sobre a ótica preventiva é baseado nos seguintes objetivos centrais da Estratégia de Segurança Nacional dos EUA: garantir a própria segurança; sustentar a sua prosperidade econômica; e promover a "democracia" e os "direitos humanos" no exterior.

Dessa forma, o Governo norte-americano valoriza os interesses do país de acordo com a importância que os mesmos possam ter para a segurança, o desenvolvimento e o bem-estar nacional, classificando-os, de acordo com o Departamento de Estado, em:

- Interesses vitais: aqueles de primordial importância para a sobrevivência, a segurança e a vitalidade da nação;

- Interesses importantes: aqueles que, embora não afetem a sobrevivência da nação, afetam o bem-estar nacional e o mundo como um todo; e

- Interesses periféricos: aqueles que levam a nação a agir porque seus valores assim o exigem, mas não têm um impacto substancial sobre o país. 


\subsection{Metas do Plano Estratégico do Departamento de Estado dos EUA}

Atuando sob chefia e coordenação do Secretário-Assistente do Departamento de Estado dos EUA e tendo como principal incumbência a promoção dos interesses norteamericanos no Hemisfério, o Bureau of Western Hemisphere Affairs, criado em 1988, é o órgão governamental daquele país que tem como responsabilidade a formulação de diretrizes e metas destinadas a estreitar e ampliar as relações com a América Latina e o Caribe. Para esse fim, provê suporte à democracia, ao comércio e ao desenvolvimento econômico sustentável e promove a cooperação em assuntos de interesse do Governo dos EUA.

Uma grande ênfase também é dada a questões de segurança, tais como crime transnacional e tráfico de drogas, segurança pública e proteção para a fronteira do país e para cidadãos norte-americanos na América Latina, e, finalmente, salvaguarda dos direitos humanos. Os Estados Unidos possuem uma série de medidas para combater ameaças dentro desse tema. Uma delas é promover o profissionalismo das forças armadas, oferecendo treinamento e equipamento para militares focalizados em missões de paz e de auxílio em caso de calamidade pública.

Outra prioridade é promover a confiança entre os países, através de convenções da OEA sobre a aquisição de armas e de apoio na resolução de conflitos regionais.

O Plano Estratégico do Departamento de Estado estabelece dezesseis metas a serem alcançadas, conforme os interesses nacionais, para a execução da política externa norteamericana, com maior ou menor grau de aplicabilidade para a América do Sul.

\subsection{Desafios de Segurança para os EUA na América do Sul}

A estratégia norte-americana para a América do Sul se fundamenta no próprio objetivo central da sua Estratégia de Segurança Nacional. Fatores políticos, econômicos e sociais existentes na América do Sul possibilitam identificar, como principais desafios a serem enfrentados na região: narcotráfico; corrupção em todos os níveis governamentais; imigração ilegal; desastres naturais; agressões ao meio ambiente; violação dos direitos 
humanos; terrorismo; contrabando de armas; e questões fronteiriças (particularmente envolvendo Venezuela, Guiana e Suriname).

Durante um ciclo de seminários realizado nos EUA, em julho de 2002, e patrocinado pelo Instituto Nacional de Estudos Estratégicos (Institute for National Strategic Studies - INSS), pertencente à Universidade de Defesa Nacional (National Defense University - NDU), o chefe da Seção de Estratégia, Política e Planejamento do Comando Sul dos EUA, considerando os principais desafios citados anteriormente, analisou os países sul-americanos e classificou-os de acordo com o "risco" que oferecem à estabilidade regional, nos aspectos político, econômico e/ou social.

Dessa forma, apenas foram excluídos o Chile, o Brasil, o Suriname, a Guiana e o Uruguai, sendo que, nos dias atuais, dificilmente este último país deixaria de ser considerado "de risco", em função do agravamento de sua situação econômica.

Portanto, a Argentina e o Equador, por questões econômicas; a Bolívia, o Peru e a Colômbia, por estarem submetidos à forte pressão de grupos produtores de drogas, com este último país envolvido, ainda, no combate a movimentos extremistas em seu território; e a Venezuela e o Paraguai, devido a problemas políticos, todos foram considerados países "de risco" no subcontinente e que podem ameaçar os interesses e os objetivos norteamericanos na região.

Com relação ao Brasil, a análise foi de que seria possível a manutenção do diálogo e do trabalho conjunto. Apenas foi manifestada a preocupação do Comando Sul dos EUA com a crescente falta de ação governamental nas grandes cidades brasileiras, com comprometimento das questões ligadas à segurança pública.

É inegável que, a despeito de existirem outros problemas de vulto na América do Sul, a ameaça proporcionada pelo narcotráfico constitui-se, aparentemente, no principal fator de preocupação da política externa dos EUA paraa América do Sul.

Segundo Pereira (2009, p. 4) as principais questões de segurança para a região, segundo o Departamento de Estado dos EUA, são creditadas aos crimes de natureza transnacional:

$\checkmark$ o aumento do número de seqüestros;

$\checkmark$ explosão do consumo de entorpecentes em todas as classes sociais;

$\checkmark$ a multiplicação das zonas de fragilidade social; 
$\checkmark$ ofuscamento da distinção entre polícia e criminoso;

$\checkmark$ a disponibilidade cada vez maior de armas leves e ligeiras;

$\checkmark$ o inchaço da população carcerária;

$\checkmark$ a elevação do número de vidas perdidas.

Esses são alguns dos vários aspectos que se alimentam desse mesmo fenômeno.

Os Estados Unidos, sendo o maior mercado consumidor de drogas, com consumo crescente, acumulavam efeitos problemáticos sobre a sua sociedade. Isso fez com que em diversos momentos o fenômeno da criminalidade na América do Sul tivesse tratamento específico e pormenorizado por parte dos agentes decisores do governo. Isso tendeu a ser cristalizado em projetos de cooperação para a repressão à produção e ao tráfico de drogas, a o tráfico de armas e também de pessoas, especialmente: crime organizado; lavagem de dinheiro; tráfico de drogas; imigração ilegal; contrabando de armas; e terrorismo.

Além disso, verifica-se internamente que os países têm comprometido suas estabilidades institucionais pela corrupção nos diferentes níveis governamentais e por sistemas legais ineficientes, que estimulam e favorecem o crime organizado, ressalta o mesmo autor.

Não é possível rotular o comércio ilícito como uma ação restrita ao submundo ou ...às zonas de exclusão da sociedade. As fronteiras entre cidadão e crimino
so, dinheiro sujo e dinheiro limpo, agentes de segurança interna e agentes
de segurança internacional, têm se nublado cada vez mais e a falta de
clareza nessas definições podem ter como tendência complicar mais do
que solucionar as dificuldades analíticas. A ambigüidade crescente entre
elementos dados muitas vezes como determinados é uma das marcas da
evolução da criminalidade que ultrapassa fronteiras. Todas essas
observações têm como pano de fundo o processo de globalização,
definido pelo aumento das relações e atividades sociais que cruzam
fronteiras, mas
pela intensidade crescente dos fluxos globais de grande vulto, fazendo co
m que os Estados e as sociedades fiquem cada vez mais vinculados a
redes de interação (Pereira, 2009, p. 4). No que diz respeito à cooperação em segurança regional, os EUA têm procurado dinamizá-la, por meio de: diálogos bilaterais; exercícios conjuntos; intercâmbios de militares (principalmente sobre o tema de manutenção da paz); reuniões regulares de Ministros da Defesa; fornecimento de equipamentos diversos; e estabelecimento e operação de bases militares, instalações de radar e de comunicações e aeródromos. 
Porém, alguns crimes teriam a característica de impactar de forma igual os três ambientes:

1. Sociedade civil;

2. Negócios e interesses financeiros; e

3. Estabilidade/segurança global.

Os crimes mais focalizados são a lavagem de dinheiro; crimes ambientais e os crimes high tech. Pereira cita, para comprovar o crescimento da ingerência norte-americana na questão da segurança regional, o "Fundo de Apoio Financeiro a Atividades Militares no Estrangeiro" (Foreign Military Financing Fund), que, segundo ele, se destina, basicamente, ao financiamento de material de emprego militar a países selecionados da região. É ressalta que os recursos desse fundo não incluem a ajuda financeira norte-americana para a execução do Plano Colômbia, concedida em 2000, da ordem de 1,3 bilhão de dólares.

Para o Departamento de Estado dos EUA, os esforços norte-americanos em encorajar a cooperação multilateral estão aumentando a confiança e a segurança na América do Sul, possibilitarão melhores condições para combater as ameaças transnacionais, particularmente as relacionadas ao narcotráfico, nos países do Arco Andino.

Além disso, podem promover a "democracia" e o "desenvolvimento econômico" na América do Sul, o que constitui um "interesse importante" para os EUA, e, certamente, contribuirá para a expansão de mercados e o fortalecimento de investimentos diretos dos EUA na Região. 


\section{CAPÍTULO 2}

\section{O COMANDO SUL DOS EUA}

O Comando do Sul dos Estados Unidos (SOUTHCOM), localizado em Miami, é uma organização militar regional unificada e um dos 10 Comandos de Combate (COCOM) do Departamento de Defesa dos EUA.

Sua responsabilidade é planejar o contingente, as operações e a cooperação das forças de segurança da América do Sul, Central e Caribe (exceto os territórios e possessões dos EUA na região, Cuba e as Bahamas e suas águas territoriais), além de operacionalizar suas decisões político-estratégicas para a América Latina e Caribe.

O Comando do Sul é ainda responsável pela segurança de toda a região do Canal do Panamá. Sua área de atuação compreende mais de 30 países do Hemisfério Sul e uma área de mais de 26 milhões de quilômetros quadrados.

A principal missão do Comando Sul dos Estados Unidos é: moldar o ambiente na sua área de responsabilidade, conduzindo o engajamento militar, com o respectivo estreitamento dos laços nesse relacionamento e executando atividades antidroga, com a finalidade de promover a democracia, a estabilidade e o desenvolvimento de soluções coletivas para as ameaças à segurança da região; quando requerido, responderá unilateralmente ou em forma multilateral às crises que ameacem a estabilidade regional ou os interesses nacionais, preparando-se, ademais, para enfrentar futuros desafios no Hemisfério. 
Figura 1 - Mapa da América Central e da América do Sul sob a jurisdição do Comando Sul dos Estados Unidos para Hemisfério Ocidental

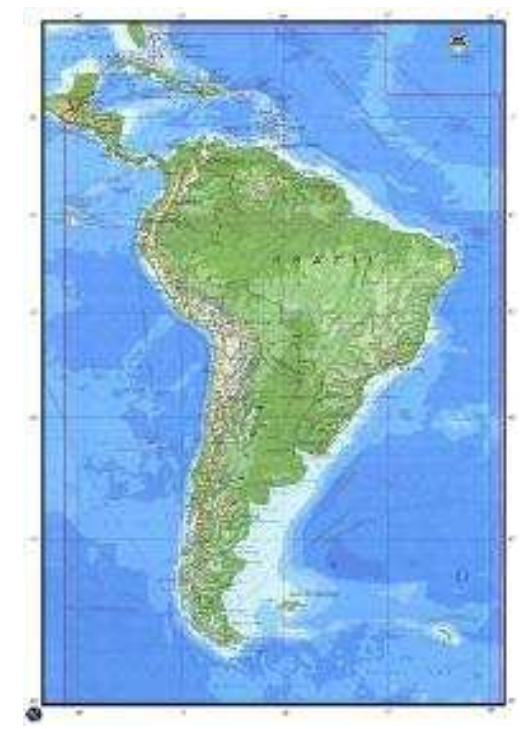

Fonte: http://www. southcom.mil/

\subsection{Estrutura do Comando Sul}

É um Comando Combinado composto por elementos do Exército, Marinha, Força Aérea e Fuzileiros Navais, além de contar com representantes do Departamento de Estado, da Drug Enforcement Administration (DEA), da Defense Intelligence Agency (DIA), da National Security Agency (NSA), da Guarda Costeira e da Alfândega, com um total aproximado de 1.300 homens e mulheres das três Forças Armadas e 180 civis.

As Forças Armadas fornecem ao Comando do Sul recursos e pessoal para suas forças tarefa: dois grupos de Operações Especiais, um de Inteligência, e gabinetes de segurança.

Quatro escolas apóiam o Comando Sul, possibilitando o treinamento no idioma espanhol para militares e civis latino-americanos: Centro de Estudos de Defesa Hemisférica (CHDS); Naval Small Craft Training (NAVSCIATTS); Inter-American Air Force Academy (IAAFA); e Wester Hemisphere Institute for Security Cooperation (WHINSEC).

$\mathrm{Na}$ estrutura organizacional do Comando Sul existe, ainda, a Joint Task ForceBravo (JTF-Bravo) e a Joint Interagency Task Force-East (JIATF-East). 
A JTF-Bravo está sediada na Soto Cano Air Base, em Honduras, e está capacitada a operar aeronaves C-5 Galaxy em apoio às chamadas atividades de "aumento da confiança".

A JIATF-East é uma organização interagências destinada a facilitar a coordenação dos esforços antidroga nas zonas de produção e tráfico, monitorando as áreas críticas de plantação de coca, a interdição das zonas produtivas e as rotas marítimas e aéreas que demandam os EUA e outros países.

O Comando Sul possui, também, o Centro de Operações Conjuntas de Reconhecimento e Vigilância (JSSROC) destinado a atividades especiais de vigilância e reconhecimento e que tem como atribuição prover observação de radar, durante operações de contingência, reportando o resultado dessa monitoração.

Sob comando e controle do Comando Sul existem três Localidades de Operações Avançadas (Forward Operating Locations - FOL), que foram criadas em substituição às organizações militares que estavam instaladas na Zona do Canal (Panamá), desativadas no final da década de 90 .

As três FOL, localizadas em Manta (Equador), Rainha Beatrix/Hato (Aruba/Curaçao) e Comalapa (El Salvador), estabelecem uma cobertura geográfica maior que a antiga Base de Howard, com um custo de manutenção cerca de 50\% menor que o despendido com as instalações no Panamá.

O principal argumento para a instalação das FOL em território estrangeiro, mediante contratos de arrendamento temporário das instalações, é a necessidade de presença contínua norte-americana no combate ao narcotráfico.

Com a operação das três FOL, os EUA têm atendida a sua estratégia de manter a presença e o monitoramento do espaço aéreo na América Latina e no Caribe, incluindo parte do território brasileiro, particularmente a região amazônica.

\subsection{Estratégia do Comando Sul}

A Estratégia do Comando Sul dos Estados Unidos (SOUTHCOM) é alcançada por meio de linhas interdepartamental e coordenação interinstitucional (formal e informal de comunicação). 
Para o cumprimento de sua missão, o Comando Sul elaborou a seguinte estratégia:

$\checkmark$ Construir uma segurança regional cooperativa, promovendo atividades que desenvolvam acordos para esse fim e medidas de aumento da confiança entre vizinhos que possam contribuir para reduzir as tensões regionais e entre os Estados;

Desenvolver um novo papel e missões para os militares da região, condizentes com o século XXI, assistindo as Forças Armadas da América Latina e do Caribe no desenvolvimento de uma apropriada estrutura de Forças e de uma doutrina que demonstre o apoio aos direitos humanos e subordinação à autoridade civil;

Apoiar a estratégia nacional de combate às drogas, promovendo o apoio militar aos esforços e programas das agências norte-americanas e aliados compromissados; e

$\checkmark$ Reestruturar o Comando Sul para o futuro, posicionando e reestruturando o Comando e suas Unidades para garantir um continuado apoio aos interesses da segurança nacional norte-americana, em sua área de responsabilidade, no século XXI.

Os principais departamentos que sincronizam e coordenam essas atividades dentro da área do Comando Sul dos Estados Unidos são: o Departamento de Estado, o Ministério da Defesa, naturalmente inseridos os embaixadores e suas respectivas equipes, Comandantes Militares do Grupo, o Departamento de Justiça e o Departamento do Tesouro.

Como acontece com qualquer organização militar americana, o conceito primário aborda o princípio da defesa preventiva, por meio de um trabalho construtivo, da promoção da democracia, estabelecendo boas relações de trabalho entre todos os países da região e desenvolvimento de um verdadeiro respeito pelos direitos humanos.

No atendimento de sua estratégia, o Comando Sul estabelece a divisão da América do Sul em duas áreas, priorizando, para cada uma, os seguintes focos de engajamento: 
$\checkmark$ Arco Andino: combate ao narcotráfico, democratização, profissionalização das Forças Armadas e combate a ameaças transnacionais.

$\checkmark$ Cone Sul: preparação das Forças Armadas para operações de paz, democratização, profissionalização das Forças Armadas e fortalecimento da segurança nacional.

$\mathrm{Na}$ conjuntura do Arco Andino, podemos verificar que o presidente nacional da Estratégia de Controle de Drogas dos Estados Unidos prevê um plano global de 10 anos para reduzir o uso de drogas e suas consequiências.

A estratégia assenta na redução da demanda na América por drogas por meio de tratamento e prevenção e atacando o fornecimento de medicamentos por meio da aplicação da lei e da cooperação internacional.

Outra principal tarefa da conjuntura Andina, no foco das operações contra o narcotráfico na América Latina, é reduzir a quantidade de cocaína e heroína contrabandeada para os Estados Unidos.

Para este fim, o Comando Sul dos Estados Unidos (SOUTHCOM), recebeu cerca de $1 \%$ por cento do Orçamento Federal Total Antidrogas (US\$ 17,8 bilhões) para apoiar os esforços das outras agências e nações comprometidas com a causa antidrogas.

Como vetor militar do Departamento de Defesa para atuar na América Latina e no Caribe, o Comando Sul dos EUA tem fortalecido sua presença na região, estabelecendo "Localidades de Operações Avançadas", de múltiplas e importantes destinações, e buscando ampliar suas relações com os governos e as Forças Armadas dos países inclusos em sua área de responsabilidade.

Esse Grande Comando é o principal instrumento que o Governo dos EUA utiliza para a consecução de sua estratégia de expansão do Poder Nacional na América Latina e no Caribe. 


\subsection{Principais atividades do Comando Sul}

Para atingir os objetivos de sua estratégia para a América do Sul, conforme os interesses e as metas da Política Externa norte-americana, o Comando Sul desenvolve as seguintes atividades na região:

- Exercícios de Operações de Manutenção da Paz;

- Treinamento combinado;

- Educação combinada;

- Assistência em segurança (fornece artigos de defesa excedentes e aumenta a capacidade de apoio às Operações de Manutenção da Paz); e

- Contatos militares (conferências, intercâmbios de pessoal especializado em assuntos militares e intercâmbios de unidades militares).

No próximo capítulo será apresentada o cenário da América do Sul onde o Comando Sul desenvolve suas atividades. 


\section{CAPÍTULO 3}

\section{CENÁRIO DE SEGURANÇA DA AMÉRICA DO SUL}

A percepção de fatores não tradicionais como fonte de ameaça à segurança dos Estados nas relações internacionais contemporâneas provocou alteração quanto ao entendimento acerca da natureza e intensidade relativa das fontes de insegurança no pósGuerra Fria.

Esse novo cenário internacional assinala para a emergência de uma agenda de temas e conteúdos de importância distinta para os Estados da América do Sul. Os riscos comuns e as percepções compartilhadas relativamente ao que pode vir a afetar a segurança dos atores relevantes na região deixaram de existir.

Apesar do surgimento de novos riscos e fatores de insegurança, não se pode deixar de observar que as questões tradicionais continuam a fazer parte das relações interamericanas e, como tal, impactam na conformação das políticas externas dos diferentes países. Enquanto durante o período da Guerra Fria os temas estratégicos dominavam a concepção sobre os problemas de segurança internacional como decorrência da temática da confrontação bipolar, no contexto contemporâneo não apenas novos problemas foram incorporados aos tradicionais, mas também novos e distintos atores passaram a ser relevantes para essa nova configuração.

Considerando-se as alterações por que passou o conceito de segurança internacional e a importância do regionalismo no pós-Guerra Fria, que permitiu um maior espaço de autonomia para que as próprias regiões passassem a se ocupar de suas agendas de segurança, o papel do Brasil nesse contexto assume relevância destacada.

Reputa-se a América do Sul como uma região de segurança, pois, dada a intensidade das interdependências, conforma-se um padrão regional entre essas relações. As percepções e as interações entre os Estados sul-americanos formariam, então, um complexo de segurança em face da interligação entre suas preocupações.

Importa destacar que a América do Sul, em particular, é uma área que se encontra livre de armas nucleares, na qual praticamente inexistiram guerras interestatais no período 
pós-Guerra Fria - embora as recorrentes situações de tensão interestatal. Por outro lado, a região ainda enfrenta problemas tradicionais de caráter fronteiriço, que se somam a questões de natureza diversificada, muitas delas derivadas de problemas intra-estatais, que vulneram a segurança dos Estados.

A região não tem estabelecido mecanismos multilaterais que sejam efetivos e suficientes para responder aos seus conflitos, além de fragmentar-se quanto a possíveis respostas comuns às fontes de insegurança e ameaças. Como conseqüência da baixa institucionalização entre os Estados - tanto no campo da segurança quanto em relação às questões econômicas, convém destacar - as resoluções das disputas se processam politicamente e não institucionalmente.

Embora as condições processadas após os atentados de 11 de setembro de 2001, sobretudo, apontem para a necessidade de intensificar e aprofundar a cooperação entre os Estados, tendo esse caráter assumido especial relevância para a região dados os crescentes níveis de insegurança, o fato de persistirem dinâmicas de rivalidade, dificulta a formação de mecanismos multilaterais estáveis para tratar as situações conflitivas.

\subsection{Narcotráfico: uma questão de segurança nacional}

O problema do narcotráfico assume lugar destacado nas questões de segurança regional, tendo em vista a relevância que assumiram os fenômenos não tradicionais nas últimas décadas, de modo a aprofundar as dificuldades de concertação entre os Estados da região, em razão de seus interesses díspares.

A economia do narcotráfico destaca-se para os países da região à medida que passa a ser uma preocupação compartilhada entre todos, dadas as externalidades negativas que provoca, constituindo-se, dessa maneira, como fator de insegurança regional. Sobretudo, a partir da política de combate às drogas empregada na Colômbia que, somadas às questões arraigadas de violência social interna, produz efeitos negativos para além das fronteiras nacionais colombianas, repercutindo na região como um todo.

Os aspectos da segurança e defesa apresentam maior relevância na agenda política sul-americana nos últimos anos, conformando movimentos de aproximação e de ruptura entre esses países. Merece destaque a implantação de medidas de confiança recíproca; a 
participação conjunta na operação das Nações Unidas no Haiti; os acordos de cooperação e defesa celebrados; a busca pela criação de instâncias de coordenação em matéria de defesa e o estabelecimento de instrumentos de cooperação em matéria de segurança entre o Brasil e seus vizinhos (do Cone Sul e andinos).

Apesar dos esforços de aproximação, situações de tensão e ruptura ainda estão presentes. Em vista disso, tem ocorrido um processo de modernização dos aparatos bélicos de diversos países. Da mesma maneira, subsistem problemas internos, como altos índices de violência social, questões resultantes do tráfico de drogas e do crime organizado, que, em última análise, se estendem para além das fronteiras nacionais, configurando-se como transnacionais. Essas demandas, que se somam aos conflitos de fronteira não resolvidos, provocam discrepâncias entre os países, agravadas pela influência de atores externos.

\subsection{As dinâmicas regionais e a questão da Colômbia e Venezuela}

A ascensão de líderes políticos com projetos de governo ideologicamente diferentes é um ingrediente a mais em relação às situações de ruptura. As recorrentes tensões entre os governos colombiano e venezuelano após a implantação do Plano Colômbia evidenciam essa situação.

A invasão do território do Equador, por parte da Colômbia, para a captura de guerrilheiros em 2008, e a assistência militar entre Equador e Venezuela contra a Colômbia em decorrência dessa situação, além dos acordos de cooperação militar da Venezuela com Bolívia e Cuba, ressaltam as discrepâncias de posições entre o governo venezuelano e colombiano. Enquanto a Colômbia, especialmente a partir do governo Uribe, executa uma política em consonância com a estratégia dos Estados Unidos na região, a Venezuela, sob o governo Chávez, se opõe frontalmente a política norte-americana.

Os fenômenos que afetam a estabilidade na América do Sul e, em última análise, dificultam uma cooperação, devido a uma série de questões tais como a instabilidade política, institucional e sócio-econômica de alguns países e se concentram, principalmente, a partir da sub-região andino/amazônica, como destaca Pagliari (2009, p. 58).

Ao observar as fontes de ameaça no contexto da América do Sul, enquanto detentora de dinâmicas próprias de segurança, atentando-se para o papel dos Estados 
Unidos na construção das questões sub-regionais, há algumas questões que estão no cerne das políticas e ações. Trata-se do fato de que permanece na região conflitos de caráter fronteiriço entre os Estados. Os crescentes gastos militares que têm ocorrido nos últimos anos e a preocupação com uma suposta corrida armamentista na região, precipitaram um tratamento das principais ameaças não tradicionais à segurança que repercutem nas dinâmicas regionais e são fortemente avaliadas pelos Estados Unidos, especialmente considerado o terrorismo e, de maneira mais central, o problema do narcotráfico a partir do conflito colombiano.

Sobre o conflito colombiano, considerando-se que os efeitos desse problema de caráter nacional repercutem na região, seja pela presença militar dos Estados Unidos como condutor de uma resposta militarizada à questão, ou em razão dos efeitos negativos decorrentes da transnacionalidade de questões como o tráfico de drogas e armas, ainda, é tratado como uma vulnerabilidade interna dos países na região, e as desigualdades e a violência são um caldo de cultura para a expansão do fenômeno das drogas e todos os seus problemas delas decorrentes.

A questão das drogas ilícitas na Colômbia é onde, de maneira mais intensa, o tratamento do problema tem sido feito seguindo a estratégia antinarcóticos dos Estados Unidos. Agora considera-se a implantação do Plano Colômbia militarizou o problema, passando a tratar uma questão de âmbito interno como regional.

A política estratégica dos Estados Unidos para a América do Sul considerando-se a descentralização de sua presença militar, bem como a relevância atribuída à sub-região andina e às questões do narcotráfico e narcoterrorismo, apresenta os desafios e as preocupações para uma cooperação sul-americana que se coloca para todos os países da América do Sul. 


\section{CAPÍTULO 4}

\section{BRASIL: REFLEXOS DA PRESENÇA MILITAR DOS EUA NA AMÉRICA DO SUL}

Cabe lembrar que Segurança é indissociável de Defesa, segundo a práxis, não admitindo dicotomia por ser, a primeira, estado ou condição permanente, e a segunda, ação ou atitude conseqüente para se contrapor a antagonismos, pressões e ameaças aos objetivos nacionais.

À Política de Segurança e Defesa, em linhas gerais, compete identificar situações adversas e ameaças potenciais de conflito, formular hipóteses, analisar os meios disponíveis e fortalecê-los, se necessário, levantar linhas de ação e buscar uma forma ou um modelo a fim de dotar o braço armado do Estado de uma estrutura capaz de dar-lhe força, consoante a Política Externa desenvolvida. O Poder Militar requer planejamento meticuloso, continuado e mantido em permanente avaliação, para se prover os recursos indispensáveis à correta estruturação e emprego das Forças Armadas, segundo a Política de Segurança e Defesa do Estado.

A nação não pode prescindir de preparação militar e permanecer em total dependência alienígena. Exemplos marcantes a História registrou ao longo dos tempos, que puseram em risco vários Estados. Eis porque o serviço militar ainda se impõe como dever cívico.

A Política de Segurança e Defesa deve proporcionar educação e preparo profissional adequados a todos os integrantes do Sistema de Defesa - civis e militares -, de modo a que se desincumbam de suas atribuições com proficiência. Para tal, faz-se necessário, cada vez mais, que os ocupantes de cargos de chefia e comando detenham conhecimentos - além dos técnico-profissionais - de História Militar, de Geopolítica, de Política e Estratégia, de Teoria de Conflitos, de Processos de Tomada de Decisões, de Relações Internacionais etc.

A prontidão da Defesa do País depende de planejamento que assegure a execução, sem solução de continuidade, de seus planos diretores, de modo a mantê-las equipadas e 
adestradas para o desempenho de seus papéis e cumprimento das suas missões, quando determinado. Para isso, é recomendável garantir no orçamento um percentual do PIB que permita ter um mínimo acreditável de poder de dissuasão.

$\mathrm{Na}$ esfera da defesa coletiva, é preciso também uma nova visão que tenha por foco prioridades estratégicas específicas. Em primeiro lugar, a preservação da soberania, da integridade territorial e do patrimônio do País; em seguida, os compromissos, de âmbito regional e mundial, para manutenção da paz entre as nações, respeitando-se as opiniões e idéias de todos os participantes da aliança, resguardados seus interesses e valores.

\subsection{Segurança e a Defesa Nacional}

Nenhum Estado pode ser compelido a cumprir missão que ultrapasse suas possibilidades e fira a respectiva soberania. A defesa coletiva deve centrar-se em cooperação e não em integração ou alinhamento automático. As Forças Armadas conhecem bem a sua missão e sabem, perfeitamente, do que necessitam para a Segurança e a Defesa Nacional. Entretanto, apesar de cultivarem elevado grau de patriotismo, não lhes incumbe, num regime democrático, impor a definição de um modelo para a estrutura de Segurança e Defesa. Numa reflexão franca, antes de enfrentar o reequipamento e a reorganização das Forças Armadas, torna-se necessário enfrentar o aspecto crucial do problema: falta de vontade política para fazê-lo ou escassez de conhecimento sobre Política de Segurança e Defesa. Sem poder solucionar este problema, as Forças Armadas acham-se impedidas de tomar qualquer iniciativa. Dependem de uma decisão política que não lhes compete, restringindo-se apenas a estudos vagos e improdutivos. O cerne do problema é relativamente simples. Exige apenas conhecimento, discernimento e coragem. O Poder Político precisa definir os cenários em que visualiza o emprego das Forças Armadas, a finalidade da intervenção e o limite máximo de engajamento, em sintonia com a Política Externa adotada pelo Estado.

Uma Política de Segurança e Defesa nacional deve ser fundamentada, para que sirva de base à adequação das Forças Armadas para atuar, efetivamente, nos cenários antevistos. Atualmente a responsabilidade pela Segurança e Defesa nacional não é exclusiva do soldado, mas de cada um e de todos os cidadãos. Segurança e Defesa, embora influenciadas 
pelas vertentes da realidade nacional e internacional em constante mutação, resultam da vontade coletiva e individual de cada um e de todos os cidadãos e são representadas pela vontade de governante e governados, e têm expressão no dever que, por lei, é exigido de todos os cidadãos indiscriminadamente. Essas reflexões acerca da segurança regional e das questões para a política externa do Brasil, que se colocam a partir da nova agenda de segurança internacional, são os elementos analisados a seguir.

Para o Brasil, nos últimos anos, os assuntos de segurança e defesa assumiram maior importância, pois muito embora a percepção de que o país não sofreria riscos provenientes de inimigos externos, a condição das novas ameaças de caráter difuso e as situações recorrentes de instabilidade regional desafiam a conformação de um entorno estável. Dessa forma, para se alcançar a estabilidade regional e responder as suas próprias vulnerabilidades assume ainda mais relevância a adoção de ações cooperativas com os vizinhos.

Na reflexão sobre os problemas contemporâneos de segurança internacional feita por este estudo, atenta-se para o papel do Brasil nas dinâmicas de seu entorno sulamericano, a partir de um contexto de emergência de novas configurações na segurança internacional e seus reflexos para a agenda regional. A análise acerca das questões de segurança para o Brasil passa por considerar a proeminência estratégica que assumiu a América do Sul em sua política externa, enquanto seu espaço mais imediato de atuação, no qual os seus interesses de segurança e os seus problemas de defesa mais diretamente se relacionam.

\subsection{O Papel do Brasil em relação à segurança na América do Sul}

Por fim, o papel do Brasil em relação à segurança na América do Sul, em face dos desafios que se apresentam a sua inserção internacional, verifica-se um cenário de política de defesa e de uma estratégia de defesa como fatores não existentes há pouco tempo na política brasileira.

Ao fazer uma reflexão sobre os problemas contemporâneos de segurança nacional e internacional, atenta-se para o papel do Brasil nas dinâmicas de seu entorno sul-americano, 
devido à emergência de novas configurações na segurança internacional e seus reflexos para a agenda regional.

A análise acerca das questões de segurança para o Brasil passa por considerar a proeminência estratégica que assumiu a América do Sul em sua política externa, enquanto seu espaço mais imediato de atuação, no qual os seus interesses de segurança e os seus problemas de defesa mais diretamente se relacionam.

As questões de segurança e defesa nacional, nos últimos anos, assumiram maior relevância com a percepção de que o País sofreria riscos provenientes de inimigos externos, com as novas ameaças de caráter difuso e as recorrentes situações de instabilidade regional, que desafiam os contornos das fronteiras do Brasil com seus vizinhos, que busca um relacionamento estável com seu entorno.

Ficou claro para o Brasil que, para se alcançar a estabilidade regional e responder as suas próprias vulnerabilidades, tornou-se necessário dar maior relevância a ações cooperativas com os vizinhos.

Embora interesse ao Brasil cooperar com os vizinhos em termos de segurança - o que efetivamente o faz - o país não tem assumido os custos da institucionalização dos instrumentos de cooperação multilateral. Considerando-se o pressuposto de que o Brasil estaria presente nas agendas das duas sub-regiões da América do Sul - Cone Sul e andina -, neste caso, a sua atuação no espaço regional produziria reflexos nas dinâmicas de ambas as subáreas.

Nesse sentido, a sua inserção internacional de segurança e a realização de seus objetivos de política externa passam pela conformação de uma base regional sólida, na qual seriam assentadas as premissas de um regime de cooperação sul-americano. A formação de um arranjo regional cooperativo refletiria no aumento das possibilidades de autonomia da América do Sul e do Brasil, em última análise, frente ao papel e interesse dos Estados Unidos na região.

Como problema a analisar, considera-se que, embora o Brasil tenha adotado, nos últimos anos, uma estratégia que privilegia a sua inserção na América do Sul como seu mais forte espaço de atuação e, ainda, o seu papel nas dinâmicas de segurança da região, seja importante tanto para o Cone Sul quanto para a zona andina, as suas iniciativas para o 
estabelecimento de arranjos cooperativos em matéria de segurança são limitadas a acordos políticos pouco institucionalizados.

São reduzidas as possibilidades de unificar a América do Sul em torno de uma agenda de segurança comum, dada a persistência de conflitos fronteiriços entre os atores estatais sul-americanos e as percepções de ameaça provenientes de atores não estatais que fragmentam as posições da região, assim como pela conformação de múltiplos acordos de intensidade variada.

Essa percepção tem levado o Brasil a empreender movimentos que incluem a transferência de maior número de tropas para a região e o estabelecimento de acordos entre países limítrofes para vigilância de fronteiras e controle do espaço aéreo, visando combater os ilícitos daquela área, tendo em vista a preocupação brasileira de que a Amazônia concentra, atualmente, os maiores focos de instabilidade e ameaças, tanto tradicionais quanto não tradicionais. Contudo, foge ao escopo deste trabalho examiná-los detidamente, assim, apenas são reputados na medida necessária para compreender a temática principal proposta.

Dessa forma, consideram-se neste estudo as ameaças não tradicionais, com ênfase na transnacionalização dos ilícitos (como o narcotráfico), eis que essas ações repercutem na segurança pública brasileira, a partir de suas conexões em âmbito interno. Tais questões, que se colocam a partir do combate aos grupos guerrilheiros e paramilitares, são importantes para o Brasil à medida que influenciam diretamente na sua segurança pública.

\subsection{Brasil - incertezas e instabilidade}

O Brasil encontra-se no quase universo comum dos países sul-americanos, com relação ao cenário de incertezas e instabilidades, nos campos político e econômico, vivendo um imprevisível ano eleitoral, e sujeito às pressões da macroeconomia mundial, com reflexos diversos, como: redução de investimentos; altas taxas de desemprego e subemprego; diminuição dos níveis de atividade econômica; e fortes pressões sobre o mercado de câmbio, além de presenciar o enfraquecimento do principal bloco econômico regional: o MERCOSUL. 
A expressão militar sente os efeitos da crise econômica nesses países e, a despeito da necessidade de se fortalecerem, para assegurar a manutenção da segurança nacional e, até mesmo, regional, as Forças Armadas dos países sul-americanos, em sua quase totalidade, observam impotentes as reduções de seus orçamentos e as conseqüentes diminuições de sua capacidade operacional.

Suas Forças Armadas, em conseqüência, ressentem-se do momento político e econômico de indefinições que vive o País e perdem, gradativamente, poder político e capacidade operativa, tornando-se incapazes, portanto, de ocupar uma maior posição de liderança junto às Forças Armadas dos demais países, em âmbito regional.

Por outro lado, os EUA adotam uma política externa agressiva com relação à América do Sul, a despeito de este subcontinente não ser prioritário para a consecução dos objetivos centrais de sua Estratégia de Segurança Nacional.

Para enfrentar as ameaças que, na ótica do Departamento de Estado norteamericano, podem comprometer a estabilidade regional e, em conseqüência, afetar seus interesses, os EUA agem nos campos político, diplomático, econômico e militar, caracterizando a expansão do Poder Nacional sobre os países sul-americanos, como conceitua o Embaixador Marcos Henrique C. Côrtes (2002, p. 47), em sua obra Fundamentos das Relações Internacionais e Conceitos de Atuação do Campo Externo,

Expansão do Poder Nacional é o processo por meio do qual a Nação amplia, naturalmente ou por decisão política, sua presença no contexto internacional, mediante ações conduzidas em todas as Expressões do Poder Nacional.

No campo militar, adotam como principais atividades: realização de exercícios conjuntos, cursos, estágios e treinamentos diversos; fornecimento de equipamentos; aumento da presença de pessoal militar em missões permanentes; realização de ações humanitárias; construção de aeródromos, estações de radar e bases militares; e assessorias diversas no combate ao narcotráfico.

Fazendo-se presente e atuante, com ilimitada disponibilidade financeira, os EUA diminuem a capacidade brasileira de assumir a natural liderança a si destinada na América do Sul e impedem que o País exerça projeção do Poder Nacional sobre seus vizinhos do Continente. 
Cada vez mais, o Brasil cede espaço para que os EUA exerçam influência na América do Sul, por incapacidade econômica, falta de objetividade geopolítica e enfraquecimento de suas Forças Armadas.

A decisão estratégica de projetar Poder Nacional sobre determinada região, ou país, requer uma forte disponibilidade financeira e uma inquestionável vontade política de assumir riscos, aspectos não presentes, momentaneamente, na conjuntura brasileira.

$\mathrm{O}$ reflexo de maior relevância, em virtude da maciça presença norte-americana, particularmente nos países que compõem o Arco Amazônico, é o verdadeiro "cinturão" ou proteção amazônica que se forma em torno do território brasileiro, com características de super dimensionamento das reais necessidades da política externa dos EUA para a América do Sul. O complexo de instalações militares, aeródromos e estações de radar e de comunicações norte-americanas, ou sob sua influência, nas proximidades das fronteiras do Brasil com seus vizinhos, confere aos EUA uma ampla capacidade de monitoramento do espaço aéreo do território brasileiro, o que pode funcionar como fator de pressão e como condicionante para as decisões da política externa brasileira.

Finalmente, os principais reflexos para o Brasil da expressiva presença norteamericana nos países da América do Sul são: diminuição da capacidade brasileira de projetar Poder em âmbito regional e a existência de um "cinturão" de instalações norteamericanas próximas às fronteiras brasileiras, principalmente na região amazônica.

A tímida atuação brasileira, em contrapartida à influência norte-americana, é motivada, presentemente, por aspectos conjunturais negativos nos campos político, econômico e militar. No entanto, enquanto o Brasil não consegue a projeção do Poder sobre seus vizinhos, os EUA utilizam as expressões política, econômica, científico-tecnológica e militar de forma constante, eficiente e progressiva, para a expansão do seu Poder Nacional na América do Sul.

Ao mesmo tempo em que os norte-americanos ampliam seu poder militar na Região, estabelecendo bases, estações de radar e de comunicações e aeródromos, entre outras atividades relevantes, as Forças Armadas dos países sul-americanos se enfraquecem, por força de orçamentos reduzidos e de políticas governamentais que priorizam, em menor escala, os assuntos ligados à Defesa. 
Cabe, ainda, uma reflexão. Essa potente estrutura militar que está sendo instalada na América do Sul, superior, talvez, à necessária para enfrentar as ameaças visualizadas para os interesses norte-americanos na Região, será desativada quando estiver controlada a questão do narcotráfico? Ou o verdadeiro "cinturão" de forças norte-americanas em torno das fronteiras brasileiras, particularmente na área amazônica, seria utilizado para outros fins, ainda não declarado? Essas e outras questões merecem estudos mais aprofundados que possam propor respostas às questões mais urgentes a uma Política de Defesa Nacional, de amplo alcance. No capítulo 5, a seguir, estão as conclusões do presente estudo, com indicação de alguns temas sobre a influência militar dos EUA na perspectiva da soberania do Brasil. 


\section{CAPÍTULO 5}

\section{CONCLUSÕES}

O Ministro de Estado da Defesa, Nelson Jobim, ao encaminhar a proposta de Estratégia Nacional de Defesa, afirma:

O Brasil é pacífico por tradição e por convicção. Vive em paz com seus vizinhos. Rege suas relações internacionais, dentre outros, pelos princípios constitucionais da não-intervenção, defesa da paz e solução pacífica dos conflitos. Esse traço de pacifismo é parte da identidade nacional e um valor a ser conservado pelo povo brasileiro.

Para ele o Brasil é um país em desenvolvimento, ele ascenderá ao primeiro plano no mundo sem exercer hegemonia ou dominação, pois o povo brasileiro não deseja exercer mando sobre outros povos. Quer que o Brasil se engrandeça sem imperar. Talvez por isso nunca tenha sido realizado no Brasil, em toda a sua história, amplo debate sobre os assuntos de defesa. Periodicamente, os governos autorizavam a compra ou a produção de novos materiais de defesa e introduziam reformas pontuais nas Forças Armadas. No entanto, nunca propuseram uma estratégia nacional de defesa para orientar de forma sistemática a reorganização e reorientação das Forças Armadas; a organização da indústria de material de defesa, com a finalidade de assegurar a autonomia operacional para as três Forças: a Marinha, o Exército e a Aeronáutica; e a política de composição dos seus efetivos, sobretudo a reconsideração do Serviço Militar Obrigatório.

Salienta o Ministro que se o Brasil quiser ocupar o lugar que lhe cabe no mundo, precisará estar preparado para defender-se não somente das agressões, mas também das ameaças. Vive-se em um mundo em que a intimidação tripudia sobre a boa fé. Nada substitui o envolvimento do povo brasileiro no debate e na construção da sua própria defesa.

Já a política externa brasileira, sob a perspectiva da soberania nacional brasileira, leva em consideração a segurança internacional, especificamente considerado o enfoque 
regional e as novas questões que se colocam no entorno imediato para o Brasil. Essa abordagem é feita a partir da agenda sul-americana e da política externa brasileira. Para tanto, analisa-se a relação entre as demandas da política externa brasileira em termos de segurança - considerando-se a estratégia de uma atuação destacada na América do Sul - e os desafios resultantes do surgimento das ameaças não tradicionais para a conformação de uma agenda comum. São especialmente considerados os desafios que se estabelecem a partir da área andina, sobretudo do conflito colombiano, eis que associados à transnacionalização de ilícitos - como o tráfico de drogas e outros problemas relacionados.

Para alguns a "insubordinação" dos governos da América Latina, particularmente na América do Sul, constituía um sinal de crise de liderança, revelador de um mal uso de recursos de poder e de equivocadas prioridades estratégicas. Ganhou força a aplicação do conceito de sobre-extensão imperial para explicar este processo, considerando-se que os EUA passaram a privilegiar de forma exagerada políticas apoiadas em seu poderio militar.

Do lado latino-americano, apesar de sua posição marginal, a região não esteve imune ao impacto de 11 de setembro. Além de sofrer as conseqüências do processo de securitização da agenda mundial, a América do Sul experimentou uma notável reversão das expectativas quanto à adequação simultânea de seus países às receitas que prescreviam o funcionamento de democracias de mercado e de construção de um novo regionalismo.

Partindo-se da idéia de que a unipolaridade concentrou o poder de agenda dos Estados Unidos em temas de segurança, no caso da América do Sul esta concentração também implicou a suspensão de sua presença como um fator de estabilidade para a Região.

Inegavelmente, com o fim da administração Bush virou-se a página do cenário de polarizações ideológicas. Os novos ventos produzidos pela chegada de Obama à Casa Branca sopraram em todo o planeta, incluindo a América Latina, especificamente a America do Sul. De fato, buscou-se somar à Região ao sentido de mudança e à enfática defesa de instituições e valores democráticos, sem promover alterações mais relevantes no status da região no conjunto de prioridades globais.

Diante dessa posição norte-americana, observa-se que a sua maior influência, no momento, faz-se sentir nos países do Arco Andino, seguramente os mais envolvidos com a repressão à produção e à comercialização de drogas ilícitas. 
O país que tem recebido a maior ajuda financeira direcionada para fortalecer a estrutura militar é a Colômbia, em função dos conflitos internos e do fato de ser o maior exportador de cocaína para os EUA. Outros países com forte presença norte-americana em seu território são a Bolívia e o Peru, também grandes produtores de drogas.

Na América do Sul, o Brasil apresenta-se como mediador e facilitador de diálogo entre os países, o que é de especial interesse dos EUA. Entre a retórica antiamericanista de Hugo Chávez (Venezuela), Evo Morales (Bolívia) e a pró-EUA de Álvaro Uribe (Colômbia) e Alan Garcia (Peru), o Brasil representa o mediador de posições, ao tentar evitar atitudes extremas de ambos os lados.

Ainda que tenha sido mantida a relevância de implantação de uma estrutura de proteção militar para o território norte-americano, o foco de sua Estratégia de Segurança Nacional passou a ser a luta sem trégua ao dito terrorismo internacional, às redes terroristas sem fronteiras e aos países não aliados que produzem armas de destruição em massa.

Dessa forma, reduziu-se ainda mais a prioridade da política externa norte-americana para a América Latina e o Caribe, no momento atual. No entanto, na sua escala de interesses nacionais, o Governo dos EUA tem um "interesse importante" a considerar no subcontinente sul-americano, que é a questão do narcotráfico. Hoje, a quase totalidade da cocaína consumida no mercado interno norte-americano é oriunda da América do Sul, particularmente da Colômbia.

Segundo CERVO (2009, p. 518), há metas importantes do Plano Estratégico do Departamento de Estado dos EUA reservadas para a América do Sul, dentre elas: o combate ao narcotráfico e a outros crimes transnacionais; o fortalecimento da "democracia" e da economia nos países da Região, com a consequiente redução das instabilidades políticas; a preservação do meio ambiente; e o respeito aos "direitos humanos".

Em conseqüência, o Governo dos EUA mantém uma política agressiva e atuante com relação à região, priorizando a presença e, em alguns casos, até mesmo a intromissão em assuntos internos, nos países com maior comprometimento com as ameaças citadas.

Assim é que, nos países do Cone Sul, a atenção está mais voltada para o fortalecimento da democracia e para as questões ligadas aos desajustes econômicos que comprometem a estabilidade regional. 
Para o Arco Andino, particularmente Colômbia, Bolívia e Peru, está destinada a maior ajuda financeira e militar, presumivelmente por serem esses países os que concentram grande produção de cocaína e abastecem o mercado consumidor dos EUA. É importante ressaltar o fato de que esses países são, também, amazônicos e absorvem uma forte presença militar norte-americana na área de selva.

Todo esse espaço obtido pelos EUA na América do Sul, por meio de presença militar, ajuda financeira e intromissão política nos assuntos internos dos países hospedeiros, debilita a condição de liderança natural que o Brasil poderia exercer no subcontinente, em função de suas potencialidades e grandeza.

Segundo a análise de Dantas Lima, o pronunciamento realizado pela secretária de Estado dos EUA, Hillary Clinton, sobre a preocupação do governo norte-americano com o surgimento de uma corrida armamentista em território sul-americano causou alvoroço na imprensa internacional e aumentou o já intenso nível de especulações sobre o futuro da região. O potencial surgimento de tensões e conflitos ganhou destaque perante os demais temas em face de tal acontecimento.

Para ele, tal afirmação encontra respaldo, de certo modo, em dados, mas há que se questionar até que ponto vai sua aplicação. Se analisados em termos porcentuais, os países da América do Sul aumentaram em 90\% os gastos com defesa entre 2003 e 2008, o que, de início, pode parecer impactante.

A presença norte-americana em bases colombianas e as diversas declarações oficiais feitas em repulsa a tal presença corroboraram com tensões que poderiam ser entendidas como elementos motivadores ao surgimento de uma corrida armamentista, já que diante de um cenário de potencial conflito o armamento se transformaria em questão vital às políticas de Estado dos países da região (DANTAS LIMA, p.1).

O cenário político sul-americano e as situações internas por que tem passado os principais atores envolvidos em tal corrida levam a conclusões diferentes que diminuem a crença na existência de uma corrida armamentista. Para o mesmo autor, por principais atores envolvidos, entende-se Brasil, Venezuela, Colômbia, Estados Unidos e Rússia. Os gastos com defesa foram ampliados na América do Sul como um todo, porém, as principais discussões da análise giram de uma forma ou de outra em torno dos atores 
supracitados.Reconhece-se, entretanto, que países como Chile e Equador também tiveram papel fundamental no aumento de gastos com defesa na América do Sul.

O cenário contexto em que desses atores é configurado por uma ausência de condições e recursos materiais, o que dificulta a realização de uma substantiva ampliação dos quadros de defesa, em especial nos avanços tecnológicos bélicos. Os gastos com defesa na América do Sul, quando observados em termos comparativos, ainda é um dos menores do globo e perde ainda mais em importância quando se é considerado que boa parte dos recursos é destinado à gastos com pessoal. A região, por não possuir guerras ou conflitos generalizados, tende a voltar suas prioridades orçamentárias para questões sociais e para a estabilidade e o crescimento econômico (DANTAS LIMA, p.2).

A consolidação da América do Sul enquanto bloco regional, mesmo que com instáveis instituições regionais e sem a presença de uma liderança efetiva de destaque, faz com que a resolução de conflitos se dê, via de regra, através de meios diplomáticos. Somase a isso o fato de que desentendimentos históricos na América do Sul têm perdido influência em decisões políticas.

No que diz respeito às tensões regionais envolvendo, principalmente, Colômbia, Equador e Venezuela, sendo que essa última se propõe a um projeto regional e aponta a possibilidade de uma invasão norte-americana como principal motivo de seus incrementos em gastos militares, a análise de necessidades internas e principalmente da construção do discurso trazem causas que parecem mais concretas e lógicas do que a presença de uma ameaça externa. Brasil e Colômbia também estão inseridos em questões relacionadas às necessidades básicas, pois possuem Forças Armadas que estão debilitadas e sucateadas e necessitam de reformas e uma estratégia conjunta de defesa em face de necessidades internas (DANTAS LIMA, p. 4).

No caso da Colômbia, o combate às FARC se afigura como principal preocupação de segurança nacional e justificativa da presença norte-americana, porquanto Uribe e seus ministros têm afirmado por repetidas vezes que os EUA enviarão tropas com o objetivo de estabelecer cooperação técnica e fortalecer o combate ao narcotráfico. Logo, a Colômbia se arma, primeiramente, em decorrência de instabilidades internas, e não regionais.

No caso brasileiro, parece existir algo similar ao caso colombiano no sentido de a renovação da defesa ir de encontro a necessidades internas. A extensa zona fronteiriça 
brasileira - em especial a amazônica - a vasta quantidade de recursos naturais, e o quadro precário em que se encontram as Forças Armadas brasileiras justificam o estabelecimento de uma Estratégia Nacional de Defesa e da compra de armamentos que crie a capacidade de defesa, caso o uso da mesma se faça necessário.

Para Elói Martins, embora não haja uma corrida armamentista clássica pela busca de um rompimento do equilíbrio de poder na região registra-se que o processo de reaparelhamento e na reatualização tecnológica das forças armadas é conduzido por diferentes lógicas estratratégicas em cada país o que explica um padrão difereciado de gasto para cada país.

O mesmo autor afirma que, no Brasil, a renovação do arsenal advém da recente retomada de um planejamento político estratégico, a partir dos governos FHC e Lula, que busca ajustar a capacidade militar por meio de uma política externa de transferência tecnológica e industrial de áreas estratégicas conjugada a uma política interna de desenvolvimento científico, tecnológico e industrial em defesa, com o objetivo maior de potencializar um papel de relevo ao país no âmbito multilateral com o pleito de ingresso como membro permanente no Conselho de Segurança da ONU, e de liderança no âmbito regional com a criação do Conselho de Defesa Sul-Americano.

Já no Chile, segundo o mesmo autor, existe um padrão constante de compra de equipamentes militares com alto conteúdo tecnológico advindo de um baixo contingente humano nas forças armadas e do mais alto orçamento de um ministério de defesa na América do Sul, que foi legado constitucionalmente pelo ex- presidente Augusto Pinochet por meio da Lei do Cobre que destina $10 \%$ das vendas do minério às forças armadas.

Elói enfatiza que no Peru, também negando uma corrida armamentista, existe uma política de reposição de equipamentos militares, com destaque para a aquisição de tanques chineses e aviões tucanos do Brasil, que tem sido feita sob o objetivo de gerar força dissuasiva, embora se balizando por equipamentos que tenham capacidade defensiva frente ao arsenal de países vizinhos, como o Chile, que possui uma sofisticada esquadrilha de caças.

E complementa que na Colômbia, a compra de equipamentos militares pouco sofisticados revela que o reaparelhamento colombiano acontece segundo este padrão de baixo conteúdo tecnológico, pois existe uma preocupação focada no emprego sistemático 
do maior contingente humano (400.000 militares) entre todas as forças armadas da América do Sul para operações contra as guerrilhas em razão do suporte trazido pelo acordo estratégico-militar com os Estados Unidos.

No caso da Venezuela, a compra diversificada de caças, tanques e metralhadoras a partir do governo de Hugo Chávez reflete uma preocupação com o rearmamento das forças armadas após 15 anos de baixos investimentos justamente em um contexto de difusão de um movimento socialista-bolivariano com perfil anti-americanista que teme agressão tanto da potência hegemônica e de seu principal alinhado político no sub-continente, a Colômbia.

$\mathrm{Na}$ Venezuela, o armamentismo poderia equivocadamente ser atribuído, de início, à busca por liderança regional na América Latina em torno de um bloco que congregaria países que buscam uma alternativa à influência norte-americana e uma nova maneira de pensar economia e Estado, dentre outras características. Contudo, a política de Chávez vai igualmente rumo à direção de necessidades internas. O que torna a Venezuela um caso único, é o fato de que pode ser argumentado que a idéia do armamentismo passa pela construção de um discurso legitimador das ações governamentais.

O mesmo autor chama atenção para o fato de a criação da imagem de um inimigo externo e comum aos "povos livres sul-americanos" tende a desviar a atenção para a política externa e minimizar a importância de uma série de problemas internos, além de tal construção ser observável nos discursos de Chávez como elemento motivador da unidade do povo venezuelano em torno de seu projeto para o país.

Assim, medidas de aumento dos gastos militares passam a ter respaldo em uma situação onde há a suposta existência, baseada em discursos, de ameaças externas Ademais do caráter da construção do discurso e justificativa da adoção de determinadas políticas, o armamentismo venezuelano pode ser interpretado como elemento de manutenção do poder de Chávez, que já declarou pretender continuar no poder após 2010.

Quanto à Venezuela, a ampliação de contratos bélicos com a Rússia não significa que haja a tentativa de criação de uma zona de influência direta por parte do governo russo na América do Sul. Como possuidora de uma das maiores indústrias armamentista do mundo, é natural que a Rússia busque expandir seus mercados e que a Venezuela, em consonância com sua política anti-ianque, compre armamentos de países que não estejam vinculados diretamente aos EUA. E, mesmo que a criação de influências e parcerias 
políticas por parte do governo russo venha a encontrar respaldo, se afigura como longínqua e utópica a possibilidade de um embate direto por poder e influência na região entre russos e norte-americanos.

Assim, fica nítido que a suposição existência de uma corrida armamentista na América do Sul passa por uma série de discursos e causas deturpadas que fogem ao contexto dos países que compõem a região. A presença norte-americana veio, neste sentido, como estopim para a produção de uma série de especulações que não se justificam nas necessidades domésticas e encontram pouco respaldo no contexto local.

Por mais que o discurso da secretária de Estado Clinton e alguns atritos políticos tragam preocupações à região, o processo de corrida armamentista envolve uma série de pressupostos e pré-requisitios que a América do Sul parece não preencher. Logo, a ideia da corrida armamentista serve muito mais como alerta à busca por entendimento político do que indicador da real existência de um processo de aumento de gastos com defesa em face de situações regionais de conflito. No entanto, enquanto o Brasil não consegue a projeção do Poder sobre seus vizinhos, os EUA utilizam as expressões política, econômica, científico-tecnológica e militar de forma constante, eficiente e progressiva, para a expansão do seu Poder Nacional na América do Sul.

Ao mesmo tempo em que os norte-americanos ampliam seu poder militar na Região, estabelecendo bases, estações de radar e de comunicações e aeródromos, entre outras atividades relevantes, as Forças Armadas dos países sul-americanos e do Brasil, em especial, se enfraquecem, por força de orçamentos reduzidos e de políticas governamentais que priorizam, em menor escala, os assuntos ligados à Defesa. 


\section{REFERÊNCIAS}

BANDEIRA, Moniz. Estado Nacional e Política Internacional na América Latina. 1. ed. São Paulo: Ed. da Universidade de Brasília, 1993.

BOBBIO, N.; MATTTEUCCI, N. PASQUINO, G. Dicionário de Política, Brasília, Editora Universidade de Brasília, 1986, 1318 p.

BRASIL. Ministério da Defesa. Comando Sul dos EUA. Brasília, DF, 2008a. Apreciação. . Estratégia nacional dos EUA. Brasília, DF, 2002b. Apreciação. CARTA INTERNACIONAL: Revista da Fundação Alexandre de Gusmão. São Paulo: FUNAG, n. 111, fev. 2008.

CENTRO DE INTELIGÊNCIA DO EXÉRCITO (Brasil). Atualização da conjuntura internacional. Brasília, DF, 2009a. Avaliação da conjuntura internacional. Brasília, DF, $2009 \mathrm{~b}$. Presença dos Estados Unidos na América do Sul. Brasília, DF, 2009c.

CERVO, Amado Luiz e Bueno, Clodoaldo. História da Política Exterior do Brasil. $3^{\text {a }}$ edição ampliada, Brasília, Editora Universidade de Brasília, 2008, 560p.

CÕRTES, Marcos Henrique C. Fundamentos das relações internacionais e conceitos de atuação no campo externo. 1. ed. Rio de Janeiro: Escola Superior de Guerra, 2002.

DANTAS LIMA, Michael William. Armamentismo na América do Sul: contexto, necessidades e discursos. Mundorama.com.br acesso em 01/03/2010.

DEFARGES, Philippe Moreau. Problemas estratégicos contemporâneos. 1a. ed. Rio de Janeiro: Biblioteca do Exército, 1999.

ESCOLA SUPERIOR DE GUERRA. Pensamento estratégico. Rio de Janeiro, 2002.

ESTADO-MAIOR DO EXÉRCITO. C 124-1: Estratégia. 3. ed. Brasília, DF, 2001. SIPLEX 4: concepção estratégica do Exército. Brasília, DF, 2002.

EXÉRCITO Sul dos EUA: a visão do comandante. Military Review, Fort Leavenworth, p. 76-80, 2. trim. 2000.

KOZARYN, Linda D. Entrevista com Comandante do Comando Sul dos EUA. [S.1.], 2002.

PAGLIARI, Graciela de Cont. O Brasil e a Segurança na América do Sul. Coleção Relações Internacionais. Juruá Editora, 2009, 264p. 
PEREIRA, Paulo R. De Clinton a Obama: a política externa norte-americana para a América Latina. In: Crime Transnacional e Segurança Internacional: aspectos recentes do relacionamento entre Estados Unidos e América Latina. Departamento de Política da PUC-SP; Observatório das Relações Internacionais (ORI/PUC-SP); Observatório das Relações Estados Unidos - América Latina (OREAL). Texto apresentado no Encontro Internacional da Associação Brasileira de Relações Internacionais - ABRI e o Inernational Studies Association - ISA, RJ, Rio de Janeiro, 22 a 24 de julho, 2009.

REBELO, Aldo. Forças Armadas e soberania nacional. 2. ed. Brasília, DF, 2002.

RICHARDSON, R. J. Pesquisa social - métodos e técnicas. São Paulo: Atlas, 2007, 334p.

Senhoras, Elói Martins. O surto rearmamentista na América do Sul. Mundorama.com.br acesso em 11/03/2010

TOSTA, Octavio. Teorias Geopolíticas. 1. ed. Rio de Janeiro: Biblioteca do Exército, 1984.

WALT, Stephen M. Walt. Beyond Bin Laden. Reshaping US Foreign Policy, vol. 26, № 3 Inverno de 2001/02, p. 56-78. 